\title{
Yeni Nesil Dizileme Teknolojileri ile Kanserde Mitokondriyal DNA Analizi
}

\section{Mitochondrial DNA Analysis by Next Generation Sequencing Technologies in Cancer}

\author{
Sirin KILICTTURGAY YÜKSEL $\stackrel{1}{1}$, Cemaliye BOYLU AKYERLi ${ }^{2}$
}

${ }^{1}$ Acıbadem Mehmet Ali Aydınlar Üniversitesi, Fen-Edebiyat Fakültesi, Moleküler Biyoloji ve Genetik Bölümü, İstanbul, TÜRKIYE

${ }^{2}$ Acıbadem Mehmet Ali Aydınlar Üniversitesi, Tıp Fakültesi, Tıbbi Biyoloji Anabilim Dalı, İstanbul, TÜRKIYE

öz.

Amaç: Hücre için başta enerji metabolizması ve yapı taşlarının üretimi olmak üzere oldukça önemli bir role sahip olan mitokondrinin kanserdeki rolü henüz tam olarak bilinmemektedir. Mitokondriyal genomdaki varyasyonlar ve polimorfizm kombinasyonları kullanılarak belirlenen haplogrupların farklı kanserlerdeki etkisi araştırılmaya devam edilmektedir. Bu nedenle, mitokondriyal genomu çoğaltarak yeni nesil yöntemlerle dizileme protokolünü optimize ederek kanser çalışmalarında kullanmayı amaçladık. Materyal ve Metod: Gliom tümör örneklerinden elde edilmiş genomik DNAlar'dan mitokondriyal genom iki ayrı reaksiyon halinde Takara LA Taq DNA polimeraz ile çoğaltılmıştır. "Nextera XT DNA Library Prep Kit" kullanılarak kütüphane oluşturulmuş ve yeni nesil dizileme MiSeq FGx cihazında gerçekleştirilmiştir. Elde edilen veriler "mtDNA Server" veritabanı kullanılarak mitokondriyal varyasyonlar, heteroplazmi oranları ve haplogruplar açısından analiz edilmiştir.

Bulgular: Mitokondriyal genom için yeni nesil dizileme protokolü optimize edilmiștir. Detaylı analiz edilen iki tümör örneğinde çeşitli varyasyonlar ve bunların heteroplazmi oranları tespit edilebilmiştir. Ayrıca, örneklere ait haplogruplar da saptanmıştır.

Sonuç: Mitokondriyal varyasyonların kanser biyolojisi üzerindeki etkisi hala araştırılmaktadır. Yeni nesil dizileme teknolojileri özellikle heteroplazmi oranı düşük tümörlerin analizinde kullanılabilecek güvenilir bir yöntemdir.

Anahtar kelimeler: Kanser, Mitokondriyal DNA, Varyasyonlar, Yeni nesil dizileme

\section{Abstract}

Background: The role of mitochondria in cancer, which has a very important role for the cell, especially in energy metabolism and the production of building blocks, is not yet fully understood. The effects of mitochondrial genome variations and haplogroups, that are determined by the combinations of polymorphisms, on different cancers are still investigated. Therefore, we aimed to optimize and use next generation sequencing protocol in cancer research by amplifying the mitochondrial genome.

Materials and Methods: Mitochondrial genome was amplified in two separate reactions with Takara LA Taq DNA polymerase from genomic DNAs obtained from glioma tumor samples. A library was constructed using the "Nextera XT DNA Library Prep Kit" and next generation sequencing was performed on MiSeq FGx device. The data were analyzed in terms of mitochondrial variations, heteroplasmy ratios and haplogroups using the "mtDNA Server" database.

Results: Next generation sequencing protocol for the mitochondrial genome was optimized. Several variations and their heteroplasmy ratios were detected for the two tumor samples that were analyzed in detail. In addition, haplogroups of these samples were also determined.

Conclusions: The impact of mitochondrial variations on cancer biology is still under investigation. Next generation sequencing technologies are a reliable method that can be used in the analysis of tumors especially with low heteroplasmy ratios.

Key Words: Cancer, Mitochondrial DNA, Next generation sequencing, Variations

\section{Sorumlu Yazar / Corresponding Author}

Dr. Şirin KILIÇTURGAY YÜKSEL

Acıbadem Mehmet Ali Aydınlar

Üniversitesi Kayışdağı cad. No:32,

34752 Ataşehir, İstanbul / TÜRKiYE

E-mail:_sirin.yuksel@acibadem.edu.tr

Received / Geliş Tarihi: 28.12.2020

Accepted / Kabul Tarihi: 17.03.2021

DOI: $10.35440 /$ hutfd. 848101 


\section{Giriş}

Mitokondri, hücrenin enerji ve hücre yapı taşlarının üretimi için vazgeçilmez bir organeldir. Kanser gibi hücre büyümesi ve çoğalmasının hızlı ve büyük ölçekte olduğu durumlarda da enerji ve yapı taşı sağladığı için anahtar roldedir. Mitokondriyal genlerde mutasyonlar sıklıkla saptanmasına rağmen, bunlar genellikle mitokondriyal enerji metabolizmasını inaktive edici nitelikte değil, biyoenerjik ve biyosentetik durumu değiştirecek şekildedir (1).

Mitokondriyal genom nükleer genoma göre son derece küçüktür ve hücre genomundan farklı olarak, matrilineal kalıtım göstermektedir $(2,3)$. Mitokondriyal genom az sayıda ve hücre sağkalımı için önemli genleri kodlamaktadır. Bu genlerin kanserde değişen ihitiyaçlara nasıl uyum sağladığı bugün için bilinmemektedir. Mitokondriyal DNA'da (mtDNA) meydana gelen ağır mutasyonlar hücre içinde normal mtDNA ile karışık halde bulunurlar (heteroplazmi) $(4,5)$. Mutant mtDNA yüzdesinin artışı, enerji metabolizmasındaki hasarı arttırmaktadır. Bu durum, bazal enerji ihtiyacının yüksek ve mevcut enerji deposunun düşük olduğu beyin dokusunun kanserlerinde daha da ön plana çıkmaktadır (5). Son yıllarda yapılan çalışmalarda ileri evre gliom olan glioblastomlarda (GBM) mtDNA mutasyonları gösterilmiştir $(6,7)$. Tümör oluşumu ile ilişkili olabilecek, özellikle mitokondriyal solunum zincir proteinlerini kodlayan genlerde, birçok mitokondriyal somatik mutasyon farklı kanserlerde bildirilmiştir (8). Ayrıca, mitokondriyal genomda insanlar ve insan toplulukları arasındaki polimorfizm kombinasyonunun meydana getirdiği haplogrupların kanser yatkınlığını direkt olarak etkileyebileceği gösterilmiştir $(1,9)$.

Bu çalışmada amacımız, genomik DNA kullanarak mitokondriyal genomu çoğaltmak ve kanser biyolojisi üzerindeki etkisini araştırabilmek için yeni nesil yöntemlerle dizilemektir. Elde edilen mitokondriyal varyasyonları, heteroplazmi oranlarını ve haplogrupları kapsayacak veriler, mtDNA'nın kanserdeki rolünün anlaşılması açısından önem taşımaktadır.

\section{Materyal ve Metod Genomik DNA izolasyonu}

$-80^{\circ} \mathrm{C}^{\prime}$ de saklanan periferik kan örneklerinden ve sıvı nitrojende saklanan gliom tümör örneklerinden QIAamp DNA Mini Kit (Qiagen, ABD) kullanılarak, üretici firmanın talimatlarına uygun şekilde genomik DNA elde edilmiştir. Arşiv tümör örnekleri Acıbadem Mehmet Ali Aydınlar Üniversitesi Beyin ve Sinir Cerrahisi öğretim üyeleri Prof. Dr. Necmettin Pamir ve Prof. Dr. Koray Özduman tarafından içtenlikle sağlanmıştır. Elde edilen DNAlar'ın konsantrasyonları ve saflığı saptanmak üzere $260 \mathrm{~nm}$ ve $280 \mathrm{~nm}$ dalga boylarında NanoPhotometer Pearl cihazı kullanılarak spektrofotometrik ölçüm yapılmıştır. A260/A280 oranı 1,8-2,0 olan DNA örnekleri saf olarak kabul edilmiştir.

\section{Mitokondriyal genomun amplifikasyonu ve kantifikas- yonu}

Tüm mitokondriyal genom iki ayrı reaksiyon halinde, $50 \mu \mathrm{l}$ hacimde 200-250 ng genomik DNA kullanılarak son konsantrasyonlar 1X LA PCR Buffer II (1,5 mM MgCl2), 1600 $\mu \mathrm{M}$ dNTP, 20 pmol ileri ve geri primerler (Tablo 1) ve 2,5 U Takara LA Taq DNA polimeraz (TakaraBio, ABD) olacak şekilde çoğaltılmıştır. Uzun (long-range) Polimeraz Zincir Reaksiyonu (PZR) koşulları ilk denatürasyon $94^{\circ} \mathrm{C}^{\prime}$ de 5 dakika sonrası 30 döngü $98^{\circ} \mathrm{C}^{\prime}$ de 15 saniye denatürasyon, $68^{\circ} \mathrm{C}^{\prime}$ de 10 saniye $\left(0,2^{\circ} \mathrm{C} /\right.$ saniye $), 60^{\circ} \mathrm{C}^{\prime}$ de 15 saniye, $68^{\circ} \mathrm{C}^{\prime}$ de 11 dakika bağlanma sonrası $72^{\circ} \mathrm{C}^{\prime}$ de 10 dakika son bağlanma olarak kullanılmıştır. Elde edilen mitokondriyal amplikonlar \%1'lik agaroz jelde kontrol edilmiş ve "Qubit dsDNA HS Assay Kit" ile Qubit Fluorometer cihazında kantifikasyonu yapılarak 0,2 ng/ $\mu \mathrm{L}$ DNA olacak şekilde normalize edilmiştir.

Tablo 1: Tüm mitokondriyal genomun çoğaltılması amacıyla kullanılan PZR primerleri

\begin{tabular}{|lll|}
\hline Primer ismi & Primer dizisi & $\begin{array}{l}\text { Ürün boyu } \\
\text { (baz çifti) }\end{array}$ \\
\hline MTL-F1* (ileri) & AAAGCACATACCAAGGCCAC & \\
MTL-R1* (geri) & TTGGCTCTCCTTGCAAAGTT & 9065 \\
MTL-F2* (ileri) & TATCCGCCATCCCATACATT & \\
& & 11171 \\
MTL-R2* (geri) & AATGTTGAGCCGTAGATGCC & \\
\hline
\end{tabular}

(*) Stawski (10)'den alınmıştır.

\section{Kütüphane hazırlanması}

Normalize edilmiş örnekler ile "Nextera XT DNA Library Prep Kit" kullanılarak üretici firmanın talimatlarına uygun şekilde kütüphane oluşturulmuştur (11). Sırasıyla, işaretleme (tagmentasyon), ikinci amplifikasyon, DNA kütüphanesinin pürifikasyonu, boncuk tabanlı normalizasyon ve kütüphanelerin birleştirilmesi aşamaları izlenmiştir.

\section{Yeni nesil dizileme ve verilerin incelenmesi}

Birleştirilmiş kütüphaneler, cihaza yüklemeye uygun şekilde seyreltildikten ve $98^{\circ} \mathrm{C}^{\prime}$ de 2 dakika denatüre edildikten sonra, "MiSeq Reagent Kit v2" kullanılarak MiSeq FGx cihazında dizilemeleri gerçekleştirilmiş, MiSeq Reporter v2.6 (Illumina, ABD, 2016) yazılımı ile FASTQ dosyaları oluşturulmuştur (12). Elde edilen R1 (Read 1 - okuma 1) ve R2 (Read 2 - okuma 2) FASTQ dosyaları paired-end (çift sonlu okuma) olarak, mtDNA Server (v1.0.7) veritabanına yüklenerek analiz edilmiştir (13).

Genomik DNA örnekleri kullanılarak yapılan mitokondriyal genomun yeni nesil dizileme aşamaları Şekil 1'de özetlenmiştir. 


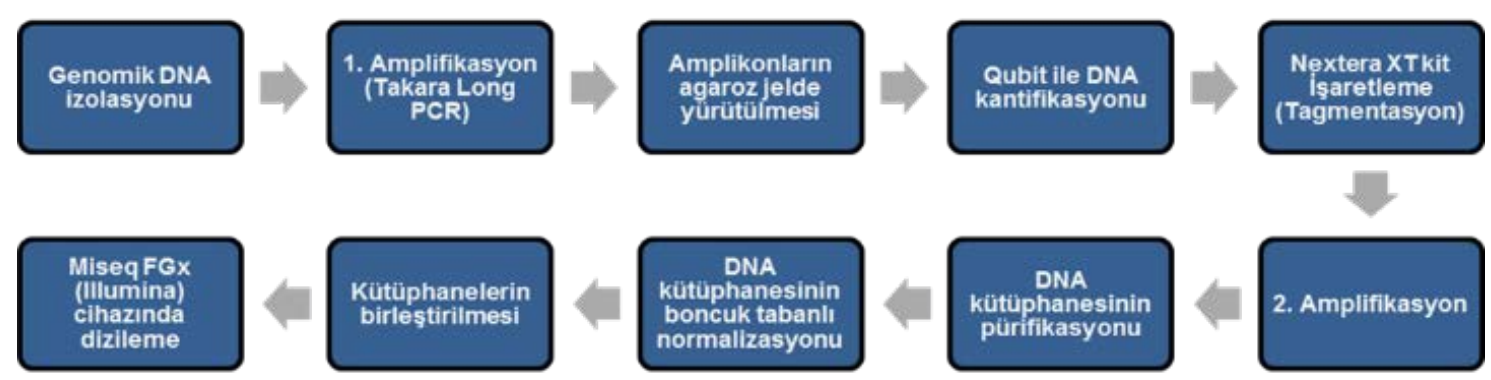

Şekil 1. mtDNA genomu yeni nesil dizileme deney akış şeması özeti

\section{Bulgular}

\section{Mitokondriyal genomun amplifikasyonu}

ilk çalışmalarda iki büyük amplikon elde etmek için kullanılan Q5-High Fidelity DNA Polimeraz (New England Biolabs, ABD) enzimi ile tek bant halinde amplifikasyon elde edilememiştir. Farklı bağlanma sıcaklıkları denenmesine rağmen sonuç elde edilemeyince (Şekil 2) kullanılan polimeraz sistemi değiştirilmiştir. Sonuç olarak, LA Taq DNA polimeraz (TakaraBio, ABD) kullanılarak farklı bağlanma sıcaklıklarında optimizasyon yapılmış ve amplifikasyon başarısı sağlanmıştır (Şekil 3).

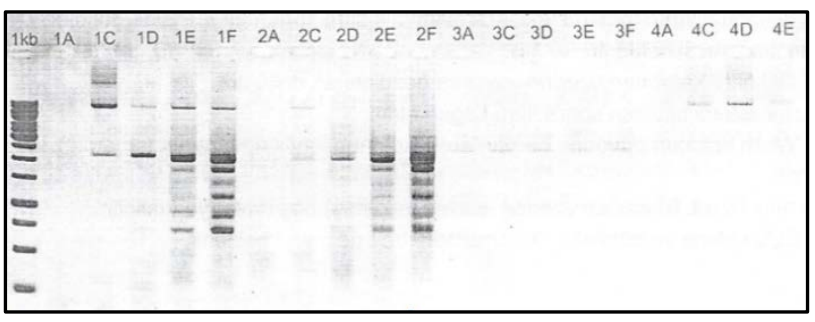

Şekil 2. Q5-High Fidelity DNA Polimeraz ile yapılan mtDNA PZR optimizasyonları. 1 ve 2 numaralı kuyular farklı iki örnek için MTL-F1 ile MTL-R1 primerleri, 3 ve 4 ise MTL-F2 ile MTL-R2 primerleri kullanılarak yapılmış optimizasyon çalışmalarıdır. A, C, D, E, $F^{\prime}$ de bağlanma sıcaklığı olarak sırasıyla $66^{\circ} \mathrm{C}, 64^{\circ} \mathrm{C}, 62,1^{\circ} \mathrm{C}, 59,8^{\circ} \mathrm{C}, 57,9^{\circ} \mathrm{C}$ kullanılmıştır. 1kb: 1kb DNA moleküler ağılık standardı.

\section{Mitokondriyal DNA yeni nesil dizileme verilerinin değer- lendirilmesi}

Tüm mitokondriyal genom iki reaksiyon halinde uygun primerler (Tablo 1) kullanılarak çoğaltılmış (Şekil 3) ve sonrasında yeni nesil dizileme gerçekleştirilmiştir. Oldukça heterojen olan glial tümörlerde, düşük heteroplazmiye sahip varyasyonların atlanmaması için daha yüksek kapsama derinliği (coverage) tercih edilmelidir. Bu çalışmadaki örneklerin kapsama derinliği (coverage) ortalama 100X'tir (Şekil 4). Ayrıca, heteroplazmi eşik değeri \%10 olarak değerlendirilmiştir.

Elde edilen veriler mitokondriyal genom analizinde oldukça önemli bir kaynak olan mtDNA Server (v1.0.7) veritabanında mitokondriyal haplogrup, varyasyonlar ve bunların heteroplazmi oranları açısından iki örnek için detaylı şekilde analiz edilmiştir. Sonuçlar revize Cambridge referans dizisi (rCRS - revised Cambridge Reference Sequence) ile karşılaştırılmıştır. Bu örneklerin birinde 12 heteroplazmik (3'ü \%10'luk eşik değerin üzerinde), 11 homoplazmik; diğerinde ise 6 heteroplazmik (1'i \%10'luk eşik değerin üzerinde) ve 13 homoplazmik varyasyon saptanmıştır. Her iki örnekte farklı varyasyonlar olsa da, ortak olan 7 adet varyasyon tanımlanmıştır (263G, 750G, 1438G, 4769G, 8860G, 15326G, 16519C). Bu varyasyonların patojenite durumları MITOMAP (14) ve HmtVar (15) veritabanları kullanılarak araştırılmıştır. Çoğunun daha önce rapor edilmiş polimorfizmler olduğu bilinmektedir. 16519C varyasyonu daha önceki çalışmalarda, GBM (6) ve prostat (16), mide (17), yumurtalık (18) gibi diğer kanserlerle ilişkilendirilmiştir. Ayrıca, haplogrup değerlendirmesi de yapılmış ve örneklerin $\mathrm{H} 28$ ve $\mathrm{H} 1 \mathrm{c} 22$ olarak Türk popülasyonunda en fazla görülen, $\mathrm{H} / \mathrm{H} 2$ haplogrubuna dahil olduğu belirlenmiştir (19).

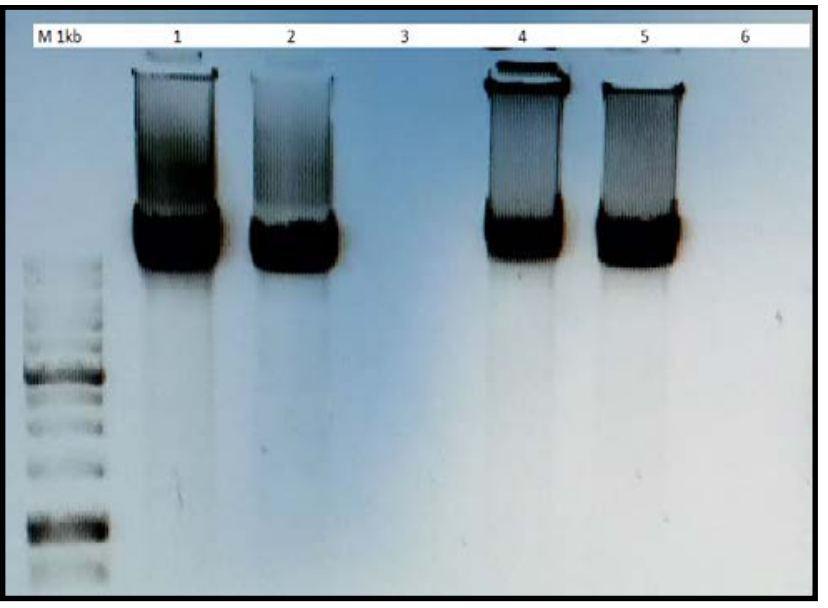

Şekil 3. Takara LA Taq polimeraz ile yapılan mtDNA PZR sonucu. Ürünler \%1'lik agaroz jelde yürütülmüştür. 1-3: MTL-F1 ve MTL-R1 primerleri ve 4-6: MTL-F2 ve MTL-R2 primerleri kullanılarak PZR yapılmıştır. 3. ve 6 . kuyularda örnek bulunmamaktadır (negatif kontrol). M1kb: 1kb DNA moleküler ağırlık standardı.

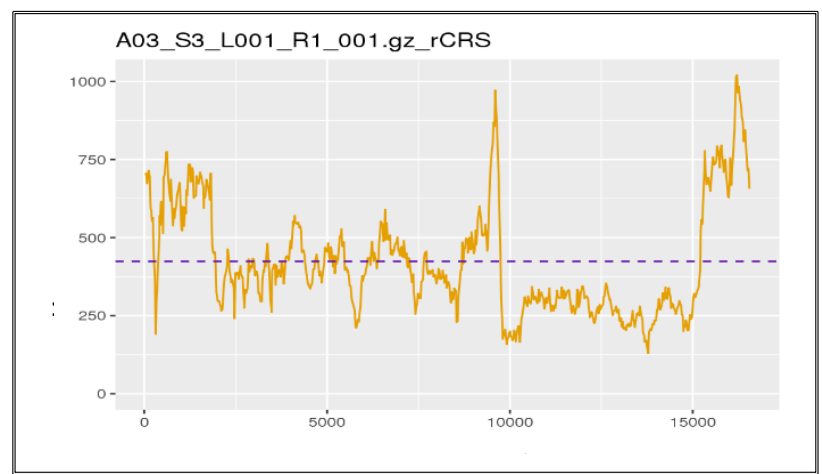

Şekil 4. mtDNA Server (v1.0.7) veritabanında analiz edilmiş örneğin kapsama derinliği grafiği. Bu örneğe ait analizde kapsama derinliği tüm mitokondriyal genom boyunca $125-1000 X^{\prime}$ tir. 


\section{Tartışma}

Hücrenin genetik kodu, hücre çekirdeği ve mitokondri olmak üzere iki farklı organelde yerleşimlidir. Nükleer genom, eşeyli kalıtılan ve hücre içi tüm olaylardan sorumlu genleri taşıyan, son derece detaylı araştırılmış bir bilgi aktarım sistemidir. Mitokondri, nükleer genoma göre çok daha küçük bir genoma sahiptir ve matrilineal kalıtım göstermektedir. Hücre biyolojisini farklı şekilde etkileyen mitokondriyal genomda, az sayıda, hücrenin yapı taşları olan ve enerji metabolizması için çok önemli enzimler kodlanmaktadır.

Paketlenme ve tamir mekanizmalarının nükleer genomdaki kadar etkin olmayışı nedeniyle, mtDNA mutasyonlara nükleer DNA'dan daha çok açıktır (20). mtDNA mutasyonları kanser de dahil olmak üzere birçok hastalıkla ilişkilendirilmiştir $(8,21,22)$. Bu çalışmada, mtDNA yeni nesil dizileme çalışma protokolünün optimizasyonu amacıyla arşiv gliom örnekleri kullanılmıştır.

Çoğunlukla ağır mutasyonlar hücre içinde normal mtDNA ile karışık halde bulunurlar. Heteroplazmi olarak bilinen bu durum, bir bireyde birden fazla mtDNA tipinin bulunmasıdır. Heteroplazmik alellerin yüzdesi, hücre bölünmeleri sırasında değişiklik gösterebilmektedir. Mutant mtDNA yüzdesinin artışı, enerji metabolizmasındaki hasarı arttırmaktadır ve doku / organın enerji gereksinimine göre fenotipe etkisi değişmektedir (5). Literatürde yapılan çalışmalarda eşik değeri genellikle $\% 20$ olarak değerlendirilmektedir (23). Çalışmamızda, tümör heterojenitesinden dolayı, düşük heteroplazmiye sahip varyasyonların atlanmaması için heteroplazmi eşik değeri \%10 olarak kabul edilmiştir.

Evrim sürecinde mtDNA'da çok sayıda mutasyon meydana gelmiştir ve bu nedenle nükleer genomda olduğu gibi, mitokondriyal genomda da insanlar arası ve insan toplulukları arası çeşitlilik oldukça fazladır. Bu değişiklikler günümüzde mitokondriyal haplogrupları belirlemek üzere kullanılmaktadır $(5,24)$. Haplogrupların mitokondriyal fonksiyon değişikliklerine neden olarak kanser yatkınlığını direkt olarak etkileyebileceği gösterilmiştir $(1,9)$.

Yeni nesil teknolojiler büyük genomların aynı anda dizilenebilmesine olanak sağlamaktadır. Yüksek kapsama derinliği nedeniyle düşük sıklıktaki varyasyonlar belirlenebildiğinden, bu yöntem kanser örneklerinin mtDNA analizinde oldukça hassas ve güvenilirdir. Bu çalışmada optimize edilen protokolde genomik DNA kullanılması, aynı örneklerden nükleer varyasyonların da çalışılabilmesine olanak sağlaması açısından önemlidir.

$\mathrm{Bu}$ protokol kullanılarak, periferik kan ve parafin kesit örneklerinden elde edilen genomik DNAlar'dan da çalışmalar yapılmıştır. Periferik kan örneklerinden mtDNA çoğaltılmış ve dizilenebilmiştir. Ancak, mtDNA yenilenmesinin (turnover) yüksek olması (25) nedeniyle hastalık biyolojisi açısından anlamlı olmayan düşük heteroplazmiye sahip çok fazla varyasyon saptanmıştır. Parafin kesit örneklerinde ise DNA'nın fragmante (parçalanmış) olması nedeniyle amplifikasyon sağlanamamıştır.
Çalışmalarda kullanılacak örnek seçimi yapılırken, bu sorunların göz önünde bulundurulması önemlidir.

Türkiye'de mtDNA yeni nesil dizileme teknolojileri konusunda öncü olan çalışmamızdaki protokol, kanser araştırmaları ve mtDNA çalışmaları yapan bilim insanlarının kullanabileceği güvenilir bir yöntemdir.

Etik onam: mtDNA yeni nesil dizileme çalışmamız, Acıbadem Mehmet Ali Aydınlar Üniversitesi Etik Kurulu ATADEK (karar no: 2016-20/16) tarafindan uygun bulunmuştur.

\section{Yazar Katkıları:}

Konsept: S..K.Y., C.B.A.

Literatür Tarama: S..K.Y., C.B.A.

Tasarımı: S..K.Y., C.B.A.

Teknik ve malzeme desteği: Ş.K.Y., C.B.A.

Veri toplama: S.K.Y., C.B.A.

Veri analizi ve yorumlama: Ş.K.Y., C.B.A.

Makale yazımı: Ş.K.Y., C.B.A.

içeriğin eleştirel incelenmesi: Ş.K.Y., C.B.A.

Çıkar Çatışması: Yazarlar çıkar çatışması beyan etmemişlerdir. Finansal Destek: ABAPKO tarafından desteklenmiştir (Proje numarası: 2018/03/02).

\section{Kaynaklar}

1. Wallace DC. Mitochondria and cancer. Nat Rev Cancer. 2012; 12(10):685-98.

2. Anderson S, Bankier AT, Barrell BG, de Bruijn MH, Coulson $A R$, Drouin J, et al. Sequence and organization of the human mitochondrial genome. Nature. 1981; 290(5806):457-65.

3. Giles RE, Blanc H, Cann HM, Wallace DC. Maternal inheritance of human mitochondrial DNA. Proc Natl Acad Sci U S A. 1980; 77(11):6715-9.

4. Stewart JB, Chinnery PF. The dynamics of mitochondrial DNA heteroplasmy: Implications for human health and disease. Nat Rev Genet. 2015; 16(9):530-42.

5. Wallace DC, Chalkia D. Mitochondrial DNA genetics and the heteroplasmy conundrum in evolution and disease. Cold Spring Harb Perspect Biol. 2013; 5(11):a021220.

6. Kirches E, Krause G, Warich-Kirches M, Weis S, Schneider $T$, Meyer-Puttlitz B, et al. High frequency of mitochondrial DNA mutations in glioblastoma multiforme identified by direct sequence comparison to blood samples. Int J Cancer. 2001; 93(4):534-8.

7. Vidone $M$, Clima R, Santorsola $M$, Calabrese $C$, Girolimetti $G$, Kurelac I, et al. A comprehensive characterization of mitochondrial DNA mutations in glioblastoma multiforme. Int J Biochem Cell Biol. 2015; 63:46-54.

8. Hertweck KL, Dasgupta $S$. The landscape of mtDNA modifications in cancer: A tale of two cities. Front Oncol. 2017; 7:262.

9. Blein S, Bardel C, Danjean V, McGuffog L, Healey S, Barrowdale $D$, et al. An original phylogenetic approach identified mitochondrial haplogroup T1a1 as inversely associated with breast cancer risk in BRCA2 mutation carriers. Breast Cancer Res. 2015; 17:61.

10. Stawski H. Preparing Whole Genome Human Mitochondrial DNA Libraries for Next Generation Sequencing Using Illumina Nextera XT. North Carolina, USA: WCU, Department of Chemistry and Physics; 2013. 
11. Illumina. Nextera XT DNA Library Prep Reference Guide: Illumina; 2019 Document \# 15031942 v05: Available from: https://support.illumina.com/content/dam/illumina-support/documents/documentation/chemistry_documentation/samplepreps_nextera/nexteraxt/nextera-xt-library-prep-reference-guide-1503194205.pdf.

12. Illumina. MiSeq Reporter Software v2.6. Illumina; USA2016.

13. Weissensteiner $H$, Forer $L$, Fuchsberger C, Schöpf B, KlossBrandstätter A, Specht G, et al. mtDNA-Server: next-generation sequencing data analysis of human mitochondrial DNA in the cloud. Nucleic Acids Res. 2016; 44(W1):W64-9.

14. MITOMAP: A Human Mitochondrial Genome Database [Internet]. [updated 1 Sep 2020; cited Nov 25, 2020]. Available from: https://mitomap.org/MITOMAP.

15. Preste R, Vitale O, Clima R, Gasparre G, Attimonelli M. HmtVar: a new resource for human mitochondrial variations and pathogenicity data. Nucleic Acids Res. 2019; 47(D1):D1202-D1210.

16. Chen JZ, Gokden N, Greene GF, Mukunyadzi P, Kadlubar FF. Extensive somatic mitochondrial mutations in primary prostate cancer using laser capture microdissection. Cancer Res. 2002; 62(22):6470-4.

17. $\mathrm{Wu} C W$, Yin $\mathrm{PH}$, Hung WY, Li AF, Li SH, Chi CW, et al. Mitochondrial DNA mutations and mitochondrial DNA depletion in gastric cancer. Genes Chromosomes Cancer. 2005; 44(1):19-28.

18. Bragoszewski $P$, Kupryjanczyk J, Bartnik E, Rachinger A, Ostrowski J. Limited clinical relevance of mitochondrial DNA mutation and gene expression analyses in ovarian cancer. BMC Cancer. 2008; 8:292.

19. Eupedia: European travel, trivia, statistics, history \& population genetics [Internet]. [updated Oct 2020; cited Nov 25, 2020]. Available from: https://www.eupedia.com/.

20. Tuppen HA, Blakely EL, Turnbull DM, Taylor RW. Mitochondrial DNA mutations and human disease. Biochim Biophys Acta. 2010; 1797(2):113-28.

21. Alston CL, Rocha MC, Lax NZ, Turnbull DM, Taylor RW. The genetics and pathology of mitochondrial disease. J Pathol. 2017; 241(2):236-50.

22. Chinnery PF. Mitochondrial disease in adults: What's old and what's new? EMBO Mol Med. 2015; 7(12):1503-12.

23. Hopkins JF, Sabelnykova VY, Weischenfeldt J, Simon R, Aguiar JA, Alkallas R, et al. Mitochondrial mutations drive prostate cancer aggression. Nat Commun. 2017;8(1):656.

24. Amorim A, Fernandes $T$, Taveira N. Mitochondrial DNA in human identification: A review. PeerJ. 2019; 7:e7314.

25. Detmer SA, Chan DC. Functions and dysfunctions of mitochondrial dynamics. Nat Rev Mol Cell Biol. 2007; 8(11):870-9. 